\title{
Efektivitas Model Pembelajaran Inside Outside Circle Didukung Media Visual Pada Pembelajaran IPA Dalam Upaya Pelestarian Sumber Daya Alam
}

\author{
Agnes Mayta Andini ${ }^{1}$, Bambang Soenarko², Muhamad Basori ${ }^{3}$. \\ Prodi PGSD FKIP Universitas Nusantara PGRI Kediri \\ agnesmayta976@gmail.com¹ํ. bambang.soenarko@gmail.com², \\ muhamadbasori45@gmail.com ${ }^{3}$.
}

Received: 08 Juli 2020; Revised: 21 Agustus 2020; Accepted: 28 Agustus 2020 DOI: http://dx.doi.org/10.37905/aksara.6.2.97-102.2020

\begin{abstract}
ABSTRAK
Penelitian ini dilatarbelakangi temuan lapangan, yang ditengarai siswa menampakkan kesan adanya kebosanan dan tampak kurang terlibat dalam aktivitas pembelajaran IPA. Hal ini disebabkan guru hanya menggunakan model pembelajaran ceramah tanpa didukung media. Mata pelajaran IPA harus menanamkan konsep ilmiah dan melakukan berbagai percobaan agar siswa mampu memecahkan masalah. Dari keberagaman model pembelajaran yang ada, salah satu model pembelajaran yang dipertimbangkan dapat digunakan untuk mewujudkan pembelajaran yang efektif yaitu model pembelajaran Inside Outside Circle (IOC). Model IOC merupakan konsep belajar yang bertujuan agar siswa dapat menyampaikan informasi dari isi materi kepada orang lain. Model IOC memiliki langkah-langkah yaitu persiapan, pelaksanaan, simpulan materi, dan evaluasi. Disamping penggunaan model pembelajaran guru dapat menggunakan media pembelajaran yang dikreasi sedemikian rupa sehingga lebih menarik minat belajar dan membangun antusiasme. Dari sekian banyak media pembelajaran, yang dipertimbangkan efektif salah satunya yaitu media visual. Media visual merupakan media yang dapat dilihat, memiliki bentuk, warna, dan tekstur dalam penyajiannya yang menarik. Dengan media visual, guru dapat meminimalkan sistem penyampaian ceramah.
\end{abstract}

Kata kunci: pembelajaran IPA, Inside-Outside Circle, dan media visual.

\section{The Effectiveness Of The Inside Outside Circle Learning Model Supported By Visual Media In The Learning Of Science In The Preservation Of Natural Resources}

\section{ABSTRACT}

This research is motivated by the findings of the field, which are suspected students show the appearance of boredom and appear to be less involved in science learning activities. This is because teachers only use the lecture learning model without the support of the media. Science subjects must instill scientific concepts and conduct various experiments so students are able to solve problems. From the diversity of existing learning models, one of the learning models considered can be used to realize effective learning, namely the Inside Outside Circle (IOC) learning model. The IOC model is a 


$\begin{array}{ll}\text { Volume : } 06 \\ \text { Nomor } & : 03 \\ \text { Bulan } & : \text { September } 2020 \\ \text { Tahun } & : 2020 \\ \text { http } & : / / \text { ejurnal.pps.ung.ac.id/index.php/Aksara }\end{array}$

learning concept that aims to enable students to convey information from the contents of the material to others. The IOC model has steps which are preparation, implementation, material conclusions, and evaluation. Besides the use of learning models, teachers can use learning media that are created in such a way that they are more interesting to learn and build enthusiasm. Of the many learning media, one that is considered effective is the visual media. Visual media is media that can be seen, has a shape, color, and texture in an attractive presentation. With visual media, the teacher can minimize the lecture delivery system.

Keywords: science learning, Inside-Outside Circle, and visual media.

\section{PENDAHULUAN}

Pendidikan di sekolah adalah tempat belajar yang paling respresentatif formal dalam menggali pengetahuan dan keterampilan kepada peserta didik. Implementasi pendidikan yang diwujudkan dalan aktifitas pembelajaran merupakan salah satu kegiatan pokok dengan guru sebagai fasilitator harus mampu mendidik dengan baik dan sejalan dengan program pendidikan Nasional. Guru sebagai ujung tombak transformasi diharapkan selain membuat suasana pembelajaran yang menyenangkan, namun harus menanamkan nilai-nilai yang berbudi luhur.

Guru profesional mampu memilih dan menerapkan model pembelajaran yang sesuai tujuan, materi, dan karakter siswa sehingga siswa dapat terlibat secara aktif untuk berkreatifitas dalam proses pembelajaran agar aspek kognitif, afektif, dan psikomotor dapat berkembang dengan baik. Ketidakmampuan guru dalam penggunaan model pembelajaran yang inovatif dapat mengakibatkan sikap siswa mudah bosan dan pasif. Kondisi ini secara langsung dan tidak langsung akan sangat berpengaruh terhadap kemampuan peserta didik.

Sebagaimana diketahui di sekolah dasar IPA diperlukan sebagai wahana manusia untuk mempelajari diri sendiri dalam kehidupan sehari-hari. Dalam pembelajaran IPA, hal paling penting yang harus dilakukan adalah menampilkan kelas sebagai ruang belajar yang mendidik, memberikan kepuasan tersendiri dengan menanamkan konsep ilmiah dan sikap yang positif terhadap siswanya melalui proses pembelajaran IPA dalam memecahkan masalah. Siswa akan selalu tertarik dengan alam sekitar dan siswa akan mengenal serta dapat memanfaatkan lingkungan sebagai sumber belajar, siswa juga akan dapat mengembangkan pikiran melalui lingkungan yang banyak memberikan pengalaman dan pengetahuan.

Dalam kenyataannya, pelakasannan pembelajaraan mata pelajaran IPA belum terjadi seperti yang diharapkan. Hal ini disebabkan guru hanya menggunakan model pembelajaran ceramah dan penugasan. Dalam pembalajaran guru hanya menggunakan LKS dan buku paket sebagai pegangan dan acuan tanpa didukung media pembelajaran. Di dalam kelas siswa terlihat pasif dan kurang bersemangat dalam kegiatan belajar mengajar. Siswa juga kurang antusias dan kurangnya minat saat mengikuti proses pembelajaran. Sehingga dalam mata pelajaran IPA siswa mendapatkan hasil nilai tugastugas, Ujian Tengah Semester, dan Ujian Akhir Semester mendapat nilai di bawah KKM.

Dari kenyataan tersebut dipandang perlu dilakukan pembenahan proses pembelajaran dan menata kembali strategi pembelajaran. Sehingga siswa dapat menjadi lebih aktif dan tidak merasa bosan dalam melakukan proses belajar. Salah satu cara untuk 


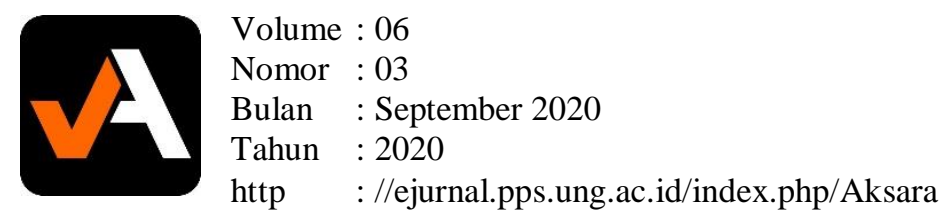

mengatasi masalah yang terjadi dalam pembelajaran dapat menggunakan model pembelajaran IOC (Inside-Outside Circle) atau Lingkaran Dalam-Lingkaran Luar. Model pembelajaran ini merupakan konsep belajar yang bertujuan agar siswa secara mandiri dapat berlatih untuk menyampaikan informasi dari isi materi kepada orang lain.

Disamping penggunaan model pembelajaran, media pembelajaran yang kreatif yaitu media yang dikreasi sedemikian rupa sehingga lebih menarik minat belajar dan membangun antusiasme dalam proses pembelajaran dengan disuguhkan kreasi gambargambar mengenai pembelajaran IPA secara sistematis untuk membantu siswa dalam bertukar informasi pembelajaran dan proses pembelajaran yang menyenangkan juga harus digunakan guru agar tercipta pembelajaran yang menyenangkan bagi peserta didik. Dari sekian banyak macam media pembelajaran, yang dipertimbangkan efektif sebagai pendukung dalam pelaksanaan pembelajaran, salah satunya yaitu media visual. Media visual merupakan media yang dapat dilihat, tidak mengandung suara, memiliki garis, bentuk, warna, dan tekstur dalam penyajiannya yang menarik agar mempermudah pemahaman siswa mengenai materi pembelajaran. Dengan media visual, siswa juga bersemangat dan termotivasi untuk mengikuti proses pembelajaran. Sehingga dapat mewujudkan pembelajaran IPA yang efektif agar tujuan pembelajaran mendapatkan hasil seperti yang diharapkan.

\section{PEMBAHASAN}

1. Tinjauan Tentang Ilmu Pengetahuan Alam (IPA)

a. Pengertian IPA

Ilmu Pengetahuan (IPA) atau sains merupakan ilmu pengetahuan yang membahas tentang peristiwa yang terjadi di alam semesta beserta isinya. Hal ini sejalan dengan pendapat Hendro 1992: 3 (dalam Samatowa 2011: 2), menyatakan bahwa "IPA adalah pengetahuan yang rasional dan objektif tentang alam dengan segala isinya". Sedangkan menurut Carin dan Sund 1993 (dalam Daryanto 2014: 190), mendefinisikan bahwa "IPA sebagai pengetahuan yang sistematis dan tersusun secara teratur, berlaku umum (universal), dan berupa kumpulan data hasil observasi dan eksperimen". IPA merupakan ilmu pengetahuan yang rasional dan objektif yang disusun secara sistematis dan sebuah kumpulan data hasil observasi dan percobaan tentang alam.

Sedangkan Menurut Susanto (2013: 167), menyatakan bahwa pengertian IPA sebagai berikut.

IPA merupakan suatu usaha manusia dalam memahami alam semesta melalui serangkaian proses ilmiah antara lain penyelidikan, penyusunan, pergaulan dan pengujian gagasan, atau dapat dikatakan menggunakan langkah-langkah ilmiah berupa metode ilmiah, pengamatan-pengamatan yang tepat pada sasaran, dan dijelaskan dengan penalaran-penalaran sehingga mendapatkan suatu kesimpulan.

Samatowa (2011: 3), juga menyatakan tentang pengertian ilmu pengetahuan yaitu:

Ilmu pengetahuan alam merupakan terjemahan kata-kata dalam bahasa Inggris yaitu natural science, artinya ilmu pengetahuan alam (IPA). Berhubungan dengan alam atau bersangkut paut dengan alam, science artinya ilmu pengetahuan. Jadi ilmu pengetahuan alam (IPA) atau 
science itu pengertiannya dapat disebut sebagai ilmu tentang alam. Ilmu yang mempelajari peristiwa-peristiwa yang terjadi di alam ini.

Selain itu IPA juga membahas tentang gejala alam yang disusun dari hasil pengamatan yang dilakukan oleh manusia. Menurut Winaputra 1992 (dalam Samatowa 2011: 3) menyatakan bahwa "IPA merupakan ilmu yang berhubungan dengan gejala alam dan kebendaan yang sistematis yang tersusun secara teratur, berlaku umum berupa kumpulan dari hasil observasi dan eksperimen (teratur)".

Dari beberapa pendapat di atas memberikan kejelasan bahwa IPA merupakan ilmu pengetahuan alam yang tersusun secara sistematis saling berkaitan untuk menjelaskan antara satu dengan yang lainnya melalui serangkaian proses ilmiah antara lain penyelidikan, penyusunan, pergaulan dan pengujian gagasan berupa metode ilmiah untuk memecahkan suatu masalah dengan cara melakukan percobaan oleh beberapa orang sehingga mendapatkan suatu kesimpulan.

b. Pembelajaran IPA

Susanto (2013: 170), mendefinisikan "pembelajaran sains merupakan pembelajaran berdasarkan prinsip-prinsip, proses yang dapat menumbuhkan sikap ilmiah peserta didik terhadap konsep-konsep IPA”. IPA merupakan ilmu pengetahuan yang menekankan keterampilan proses untuk memberikan pengalaman secara langsung dengan didasarkan pada sikap ilmiah siswa. Menurut Carin dan Sund 1989 (dalam Samatowa 2011: 20) IPA memiliki tiga komponen yaitu.

1) Proses atau metode yang meliputi pengamatan, membuat hipotesis, merancang dan melakukan percobaan, mengukur dan proses-proses pemahaman kealaman lainnya, 2) Produk, meliputi prinsip-prinsip, hukum-hukum, teori-teori, kaidah-kaidah, postulat-postulat, dan sebagainya, dan 3) Sikap, misalnya mempercayai, menghargai, mananggapi, menerima, dan sebagainya.

Sedangkan menurut Susanto (2013: 167-169), IPA memiliki tiga komponen yaitu

1) Ilmu pengetahuan alam sebagai produk, yaitu kumpulan hasil penelitian yang telah ilmuan lakukan dan sudah membentuk konsep yang telah dikaji sebagai kegiatan empiris dan kegiatan analitis. Bentuk IPA sebagai produk, antara lain: fakta-fakta, prinsip, hukum, dan teori IPA, 2) Ilmu pengetahuan sebagai proses, yaitu untuk menggali dan memahami pengetahuan tentang alam. Karena IPA merupakan kumpulan fakta dan konsep, maka IPA membutuhkan proses dalam menemukan fakta dan teori yang akan digeneralisasi oleh ilmuan. Adapun proses dalam memahami IPA disebut dengan keterampilan proses sains (science process skills) adalah keterampilan yang dilakukan oleh para ilmuan, seperti mengamati, mengukur, mengklasifikasikan, dan menyimpulkan, dan 3) Ilmu pengetahuan sebagai sikap, yaitu sikap yang harus dimiliki oleh seorang ilmuan dalam melakukan penelitian untuk mengkomunikasikan hasil penelitiannya. Sikap ilmiah juga dikembangkan melalui kegiatan-kegiatan siswa dalam pembelajaran 
IPA saat melakukan diskusi, percobaan, simulasi, dan kegiatan proyek di lapangan.

Dengan demikian pembelajaran IPA di sekolah dasar merupakan proses pembelajaran berdasarkan pada proses untuk mengembangkan keterampilan melalui diskusi maupun percobaan sehingga siswa dapat berpikir secara kritis terhadap suatu masalah yang bersifat ilmiah.

c. Karakteristik Pembelajaran IPA

Setiap mata pelajaran selalu memiliki karakteristik tertentu. Perbedaan karakteristik dari berbagai mata pelajaran menimbulkan perbedaan cara siswa untuk belajar dari mata pelajaran satu dengan yang lainnya. Demikian halnya pada mata pelajaran IPA juga memiliki karakteristik sebagai dasar untuk memahaminya. Menurut Harlen (dalam Bundu 2006: 10), tiga karakteristik utama IPA antara lain:

1) Setiap orang berhak untuk menguji kebenaran prinsip atau teori ilmiah. Artinya dalam proses pembelajaran, setiap anak diminta untuk membuktikan kebenarannya prinsip dan teori ilmiah tersebut dengan melakukan percobaan, 2) Memberikan pengertian bahwa teori yang disusun harus didukung oleh fakta-fakta yang ditemukan dari hasil kegiatan observasi dan data-data yang telah teruji kebenarannya, dan 3) Memberi makna bahwa teori sains yang ditemukan kemungkinan dapat berubah sewaktu-waktu atas dasar perangkat pendukung teori tersebut. Sedangkan menurut Jacobson dan Bergman (dalam Susanto 2013: 170), menyatakan bahwa dalam pembelajaran IPA antara lain:

1) IPA merupakan kumpulan konsep, prinsip, hukum, dan teori, 2) Proses ilmiah dapat berupa fisik dan mental, serta mencermati fenomena alam, termasuk juga penerapannya, 3) Sikap keteguhan hati, keingintahuan, dam ketekunan, dalam menyingkap rahasia alam, 4) IPA tidak dapat membuktikan semua akan tetapi hanya sebagian atau bebrapa saja, dan 5) Keberanian IPA bersifat subjektif dan bukan kebenaran yang bersifat objektif.

Dengan demikian karakteristik pembelajaran IPA berkaitan dengan konsep teori yang didukung oleh fakta-fakta dalam kehidupan sehari-hari agar siswa mudah untuk mengembangkan sikap ilmiah dan mengembangkan rasa ingin tahu untuk menggali, mengkaji informasi, dan mengambil sebuah kesimpulan dari konsep-konsep IPA.

d. Tujuan Pembelajaran IPA

Pada dasarnya IPA sangat penting bagi siswa untuk mempelajari dan menggali informasi dari berbagai macam fenomena yang terjadi di alam. Sebagaimana ditegaskan Samatowa (2011: 6), tujuan pembelajaran IPA anatara lain:

1) Bahwa IPA bertujuan untuk bagi suatu bangsa, kiranya hal itu perlu dipersoalkan panjang lebar. Kesejahteraan materil suatu bangsa banyak sekali tergantung pada kemampuan bangsa itu dalam bidang IPA, sebab IPA merupakan dasar teknologi, dan disebut-sebut sebagai tulang punggung pembangunan, 2) IPA merupakan suatu mata pelajaran yang melatih atau mengembangkan kemampuan berpikir kritis, 3) Apabila 
IPA diajarkan melalui percobaan-percobaan yang dilakukan sediri oleh anak, maka IPA tidaklah merupakan mata pelajaran yang bersifat hafalan belaka, dan 4) Mata pelajaran IPA mempunyai nilai-nilai pendidikan yaitu dapat membentuk kepribadian anak secara keseluruhan.

Sedangkan Badan Nasional Standar Pendidikan 2006 sebagaimana dikutip Susanto (2013: 171-172), bahwa mata pelajaran IPA bertujuan agar peserta didik memiliki kemampuan sebagai berikut:

1) Memperoleh keyakinan terhadap kebesaran Tuhan Yang Maha Esa berdasarkan keberadaan keindahan, dan keteraturan dalam ciptaan-Nya, 2) Mengembangkan pengeahuan dan konsep-konsep IPA yang bermanfaat dan dapat diterapkan dalam kehidupan sehari-hari, 3) Mengembangkan rasa ingin tahu, sikap positif dan kesadaran tentang adanya hubungan yang saling mempengaruhi antara IPA, lingkungan, teknologi dan masyarakat 4) Mengembangkan keterampilan proses untuk menyelidiki alam sekitar, memcahkan masalah, dan membuat keputusan, 5) Meningkatkan kesadaran untuk berperan serta dalam memelihara, menjaga, dan melestarikan lingkungan alam, 6) Meningkatkan kesadaran untuk menghargai alam dan segala keteraturannya sebagai salah satu ciptaan Tuhan, dan 7) Memperoleh hasil pengetahuan, konsep, dan keterampilan IPA sebagai dasar untuk melanjutkan pendidikan ke SMP.

Dengan demikian mata pelajaran IPA sangat penting dikuasai siswa untuk melatih mengembangkan konsep tertentu sehingga siswa dapat berpikir serta bertindak secara rasional dan kritis terhadap suatu persoalan yang bersifat ilmiah disekitar lingkungannya, melakukan berbagai eksperimen atau percobaan untuk memecahkan suatu masalah dan menghasilkan sebuah keputusan, sehingga siswa dapat menerapkan dalam kehidupan sehari-hari.

e. Ruang Lingkup Pembelajaran IPA

IPA merupakan ilmu pengetahuan yang membahas tentang alam semesta dengan segala isinya. Maka dalam mata pelajaran IPA perlu diciptakan suatu pembelajaran untuk siswa agar menimbulkan rasa ingin tahu untuk menggali informasi dari berbagai pengetahuan baru.

Ruang lingkup pembelajaran IPA di sekolah dasar dalam kurikulum 2013 berdasarkan Peraturan Menteri Pendidikan dan Kebudayaan Republik Indonesia Nomor 21 Tahun 2016 Pasal 1 Ayat 3 Tentang Standar Isi Pendidikan Dasar dan Menengah sebagai berikut.

Ruang lingkup mata pelajaran IPA di SD mencakup tubuh dan panca indera, tumbuhan dan hewan, sifat dan wujud benda-benda disekitar, alam semesta dan kenampakannya, bentuk luar tubuh hewan dan tumbuhan, daur hidup makhluk hidup, perkembangbiakan tanaman, wujud benda, gaya dan gerak, bentuk dan sumber energi alternatif, rupa bumi dan perubahannya, lingkungan, alam semesta, sumber daya alam, iklim dan cuaca, rangka dan organ tubuh manusia dan hewan, makanan, rantai makanan, keseimbangan ekosistem, perkembangbiakan makhluk 
hidup pada lingkungan, kesehatan dan sistem pernafasan manusia, perubahan dan sifat benda, hantaran panas, listrik dan magnet, tata surya, campuran dan larutan.

Berdasarkan pernyataan di atas ruang lingkup pembelajaran IPA di sekolah dasar terdiri dari berbagai konsep-konsep maupun fenomenafenomena di alam semesta yang dikembangkan secara sederhana agar siswa mudah memahami dalam pembelajaran tersebut sehingga dapat diterapkan dalam kehidupan sehari-hari.

2. Materi IPA Tentang "Upaya Pelestarian Sumber Daya Alam".

a. Pengertian Sumber Daya Alam

Sumber daya alam adalah semua kekayaan yang ada di alam yang berguna bagi kehidupan manusia. Sumber daya alam meliputi tumbuhan, hewan, dan benda tak hidup. Hal ini sejalan dengan pendapat Norhayati (2006: 125), "sumber daya alam yaitu segala kekayaan di alam pada suatu tempat yang meliputi benda yaitu sumber daya alam yang dapat diperbaharui dan sumber daya alam yang tidak dapat diperbaharui".

b. Macam-Macam Sumber Daya Alam

1) Sumber Daya Alam Dapat Diperbaharui

Yaitu sumber daya alam yang apabila habis dapat dihasilkan kembali, seperti: a) tumbuhan, b) hewan, c) tanah, d) air, dan e) hutan.

2) Sumber Daya Alam Tidak Dapat Diperbaharui

Yaitu sumber daya alam yang akan habis jika dipakai secara terus menerus. Sumber daya alam yang tidak dapat diperbaharui akan habis karena manusia maupun makhluk hidup yang lain tidak dapat menggantinya, seperti: a) bahan galian contohnya: besi, alumunium, timah, emas, perak, tembaga, dan nikel, b) bahan tambang contohnya: minyak bumi dan batu bara.

\section{c. Upaya Pelestarian Sumber Daya Alam}

Sumber daya alam yang dapat diperbaharui harus dilestarikan. Sedangkan sumber daya alam yang tidak dapat diperbaharui harus dikelola secara baik dan cermat. Kesinambungan tersedianya sumber daya alam bergantung pada cara manusia memanfaatkannya. Usaha-usaha yang dapat dilakukan untuk melindungi dan melestarikan sumber daya alam seperti: 1) penghijauan, 2) terasering, 3) reboisasi, 4) mengatur penggunaan sumber daya alam dengan bijaksana, dan 5) mencegah pencemaran udara, air, dan tanah. Selain itu ada beberapa tindakan yang menunjukkan kepedulian terhadap sumber daya alam, yaitu 1) menanami tanah yang gundul dengan tanaman hijau, 2) melindungi kehidupan hewan-hewan di hutan, 3) menjaga dan melestarikan lingkungan, dan 4) hemat menggunakan minyak bumi. Sedangkan tindakan-tindakan yang merusak sumber daya alam yaitu: 1) menebangi pohon di hutan sembarangan, 2) menagkap ikan menggunakan peledak, 3) membunuh hewan yang dilindungi undang-undang, 4) mencemari udara, air, dan tanah, dan 5) menggunakan minyak bumi secara berlebihan.

Pengawetan tanah erat hubungannya dengan pengawetan hutan dan air. Cara pengambilan kayu di hutan harus diatur dan digunakan sebaik mungkin. 
Karena hutan merupakan sumber kehidupan bagi makhluk hidup dan sebagai penghasil terbesar. Selain itu erosi perlu diadakan pencegahan agar tanah tidak terkikis dan menyebabkan longsor.

Hutan yang gundul menyebabkan banjir dan erosi. Apabila hutan tidak gundul, akar-akar pohon dalam hutan menahan lapisan di lereng pegunungan sehingga tanah tidak terbawa air yang mengalir. Membuang sampah sembarangan mengakibatkan perairan kekurangan oksigen. Sehingga ikan-ikan dan binatang air lainnya tidak dapat bertahan hidup. Sebagai manusia seharusnya saling melindungi dan menjaga kelestarian alam. Termasuk menjaga kekayaan alam dan lingkungan hidup. Hewan dan tumbuhan merupakan bagian dari lingkungan hidup yang harus dijaga dan diperhatikan. Beberapa hewan dan tumbuhan dilindungi oleh undang-undang di Indonesia. Misalnya, badak, burung cendrawasih, komodo, harimau, dan bunga raflesia atau bunga bangkai.

\section{Model Pembelajaran Inside Outside Circle (IOC)}

a. Pengertian Model Inside Outside Circle (IOC)

Menurut Huda (2013: 247), "model Inside-Outside Circle (IOC) atau Lingkaran Dalam-Lingkaran Luar dikembangkan pertama kali oleh Spencer Kagan (1990). Strategi ini memungkinkan siswa untuk saling berbagi informasi pada waktu yang bersamaan. Model pembelajaran ini dapat diterapkan untuk beberapa mata pelajaran. Sehingga siswa memiliki pengetahuan dan keterampilan yang dapat diterapkan dalam suatu permasalahan".

Shoimin (2014: 87), menyatakan bahwa model pembelajaran InsideOutside Circle yaitu "model pembelajaran dengan sistem lingkaran kecil dan lingkaran besar yang diawali dengan pembentukan kelompok besar dalam kelas yang terdiri dari kelompok lingkaran dalam dan kelompok lingkaran luar

Sedangkan menurut Suyatno (2009: 69), menyatakan bahwa "model pembelajaran IOC adalah model pembelajaran dengan sistem lingkaran kecil dan lingkaran besar dimana siswa saling membagi informasi pada saat yang bersamaan dengan pasangan yang berbeda dengan singkat dan teratur. Rusman (2013: 21), menyatakan bahwa "model pembelajaran Inside Outside Circle adalah model pembelajaran dengan sistem lingkaran kecil dan lingkaran besar yang diawali dengan pembentukan kelompok besar dalam kelas yang terdiri kelompok lingkaran dalam dan kelompok lingkaran luar.

Dari beberapa pendapat di atas, model pembelajaran Inside-Outside Circle adalah konsep belajar yang terdiri dari kelompok lingkaran dalam dan luar yang saling membagikan informasi dari isi materi yang telah disampaikan, semua siswa akan saling memberikan dan mendapat informasi pembelajaran secara bersamaan, yang bertujuan agar siswa secara mandiri dapat berlatih untuk menyampaikan informasi kepada orang lain dan dapat mengembangkan pengetahuan dan keterampilan dalam memecahkan suatu masalah. 


\section{b. Kegunaan Model Inside Outside Circle (IOC)}

Kegunaan model Inside Outside Circle sangat penting untuk menggali rasa ingin tahu siswa dan meningkatkan pemahaman konsep siswa pada pembahasan dan keterlibatan siswa untuk menemukan materi pembelajaran.

Menurut Shoimin (2014: 88), menyatakan bahwa "kegunaan model Inside-Outside Circle yaitu melatih siswa belajar mandiri dan berbicara menyampaikan informasi kepada orang lain, selain itu juga melatih kedisiplinan dan ketertiban". Model pembelajaran Inside Outside Circle bertujuan untuk melatih siswa agar dapat menyampaikan informasi kepada siswa lain siswa pada saat yang bersamaan dan melatih kedisiplinan saat pelaksanaan pembelajaran.

Sedangkan menurut Huda (2013: 247), menyatakan bahwa "strategi ini memiliki struktur yang jelas dan memungkinkan siswa untuk saling berbagi informasi dengan singkat dan teratur, selain itu siswa memiliki banyak kesempatan untuk mengolah informasi dan meningkatkan keterampilan berkomunikasi”.

Dari pendapat di atas disimpulkan bahwa kegunaan model pembelajaran Inside-Outside Circle yaitu meberikan suatu wadah kepada siswa agar lebih aktif dan antusias, meningkatkan keterampilan berkomunikasi untuk membagi informasi materi yang telah disampaikan oleh guru dengan singkat dan teratur agar sikap kedisiplinan dan ketertiban dari dalam diri siswa berkembang.

c. Langkah-langkah Model Inside Outside Circle (IOC)

Model pembelajaran Inside-Outside Circle memiliki langkah-langkah saat digunakan dalam proses pembelajaran. Langkah-langkah tersebut digunakan agar tujuan pembelajaran dapat tercapai sehingga siswa memahami konsep materi yang disampaikan oleh guru.

Menurut Shoimin (2014: 88), langkah-langkah dalam menggunakan model pembelajaran Inside-Outside Circle sebagai berikut.

1) Pendahuluan

Fase 1 : Persiapan

a) Guru melakukan apersepsi

b) Guru menjelaskan tentang pembelajaran Inside-Outside Circle

c) Guru menyampaikan tujuan pembelajaran

d) Guru memberikan motivasi

2) Kegiatan Inti

Fase 2 : Pelaksanaan pembelajaran kooperatif tipe Inside-Outside Circle

a) Membagi siswa menjadi beberapa kelompok yang beranggotakan 3-4 orang.

b) Tiap-tiap kelompok mendapat tugas mencari informasi berdasarkan pembagian tugas dari guru.

c) Setiap kelompok belajar mandiri, mencari informasi berdasarkan tugas yang diberikan.

d) Setelah selesai, seluruh siswa berkumpul saling membaur (tidak berdasarkan kelompok). 


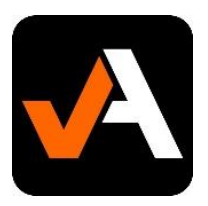

$\begin{array}{ll}\text { Volume } & : 06 \\ \text { Nomor } & : 03 \\ \text { Bulan } & : \text { September } 2020 \\ \text { Tahun } & : 2020 \\ \text { http } & : \text { //ejurnal.pps.ung.ac.id/index.php/Aksara }\end{array}$

e) Separuh kelas lainnya membentuk lingkaran di luar lingkaran pertama, menghadap ke dalam.

f) Dua siswa yang berpasangan dari lingkaran kecil diam di tempat, sementara siswa yang berada di lingkaran besar bergeser satu atau dua langkah searah jarum jam.

g) Sekarang giliran siswa berada di lingkaran besar yang membagi informasi. Demikian seterusnya, sampai seluruh siswa selesai berbagi informasi.

h) Pergerakan baru dihentikan jika anggota kelompok lingkaran dalam dan luar sebagai pasangan asal bertemu kembali.

3) Penutup

Fase 3 : Penutup

a) Dengan bimbingan guru siswa membuat simpulan dari materi yang telah didiskusikan.

b) Guru memberikan evaluasi atau latihan soal mandiri.

c) Siswa diberi pekerjaan rumah.

Spenser (dalam Aqib 2013: 30), langkah-langkah model Inside Outside Circle yaitu:

1) Separuh peserta didik berdiri membentuk lingkaran kecil dan menghadap keluar, 2) Separuh peserta didik lainnya membentuk lingkaran di luar lingkaran pertama, menghadap ke dalam, 3) Dua peserta didik yang berpasangan dari lingkaran kecil dan besar berbagi informasi. Pertukaran informasi ini bisa dilakukan oleh semua pasangan dalam waktu yang bersamaan, 4) Kemudian peserta didik berada di lingkaran kecil diam di tempat, sementara peserta didik yang berada di lingkaran besar bergeser satu atau dua langkah searah jarum jam, dan 4) Sekarang giliran peserta didik berada di lingkaran besar yang membagi informasi. Demikian seterusnya.

Sedangkan menurut Huda (2013: 247), pelaksanaan model Inside Outside Circle dapat dilakukan berdasarkan jumlah siswa dalam lingkaran individu dan lingkaran kelompok. Penjelasannya sebagai berikut.

1) Lingkaran Individu

a) Separuh kelas (atau seperempat jika jumlah siswa terlalu banyak) berdiri membentuk lingkaran kecil berdiri melingkar dan menghadap keluar. Separuh kelas lagi membentuk lingkaran besar berdiri menghadap ke dalam.

b) Setiap pasangan siswa dari lingkaran kecil dan besar saling berbagi informasi. Siswa yang berada di lingkaran kecil (lingkaran dalam) dipersilakan memulai terlebih dahulu.

c) Siswa yang berada di lingkaran kecil diam di tempat, sementara siswa yang berada di lingkaran besar bergeser satu atau dua langkah searah perputaran jarum jam.

d) Kemudian siswa yang berada di lingkaran besar untuk membagi informasi. Dan seterusnya. 
2) Lingkaran Kelompok

a) Satu kelompok berdiri di lingkaran kecil menghadap keluar. Kelompok lain berdiri di lingkaran besar.

b) Setiap kelompok berputar seperti prosedur lingkaran individu yang dijelaskan di atas dan saling berbagi informasi. berikut.

Dengan demikian langkah-langkah model Inside-Outside Circle sebagai

1) Persiapan

a) Melakukan apersepsi sebagai pengait antara pembelajaran yang sudah dilaksanakan dengan pembelajaran yang akan dilaksanakan

b) Menjelaskan tentang pembelajaran model Inside-Outside Circle

c) Menyampaikan tujuan pembelajaran.

d) Memberikan motivasi.

2) Pelaksanaan model Inside Outside Circle

3) Penutup

a) Membuat simpulan materi

b) Memberikan evaluasi

d. Kelebihan dan Kekurangan Model Inside Outside Circle (IOC)

Model pembelajaran Inside-Outside Circle memiliki kelebihan dan kekurangan setiap proses pembelajaran. Menurut Shoimin (2014: 90), "kelebihan model pembelajaran Inside-Outside Circle antara lain: 1) Tidak ada bahan spesifikasi yang dibutuhkan untuk strategi sehingga dapat dengan mudah dimasukkan ke dalam pelajaran, 2) Kegiatan ini dapat membangun sikap kerja sama antar siswa, dan 3) Mendapatkan informasi yang berbeda pada saat bersamaan".

Sedangkan yang menurut Shoimin (2014: 90) "kekurangan model pembelajaran "Inside Outside Circle antara lain:"1) Membutuhkan ruang kelas yang besar, dan 2) Terlalu lama sehingga tidak konsentrasi dan disalahgunakan untuk bergurau, serta rumit untuk dilakukan".

Penyelesaian untuk kelemahan model pembelajaran Inside-Outside Circle dapat dilakukan dengan cara sebagai berikut: 1) Apabila ruang kelas sempit dan tidak dapat digunakan untuk melaksanakan model pembelajaran Inside-Outside Circle, guru dapat menggunakan fasilitas yang disediakan sekolah yaitu aula. Aula memiliki ruang yang cukup luas sehingga proses pembelajaran akan berjalan secara efektif dan efesien dan 2) Model pembelajaran ini cenderung terlalu lama sehingga siswa tidak konsentrasi dan bergurau. Solusi yang dapat dilakukan, yaitu dengan cara menerapkan time limit atau batasan waktu. Dengan batasan waktu dalam mengerjakan tugas yang sudah dirancang guru sedemikian rupa, maka setiap siswa anggota kelompok harus menyelesaikan tugasnya sendiri agar berkonsentrasi dan tidak menyalahgunakan kerja kelompok untuk bergurau. Apabila model pembelajaran ini rumit untuk dilakukan, maka sebelum proses pembelajaran dilaksanakan, sebaiknya guru memberikan penjelasan terlebih dahulu. 
4. Media Pemebelajaran Visual

a. Pengertian Media Visual

Arsyad (2009: 3) menyatakan bahwa "media berasal dari bahasa latin medius yang secara harfiah berarti tengah, perantara, atau pengantar. Dalam proses pembelajaran perlu adanya dukungan dari media agar memudahkan siswa dalam memahami materi pembelajaran. Dari berbagai macam media yang dipertimbangkan efektif, salah satunya yaitu media visual. Menurut Sundayana (2013: 13), bahwa. "media visual yaitu media yang hanya dapat dilihat saja, tidak mengandung unsur suara. Sedangkan menurut Sanjaya (2008: 211) "media visual yaitu media yang dapat dilihat saja, tidak mengandung suara". Dengan demikian, Media visual merupakan sebuah media yang hanya dapat dilihat dengan panca indera dan tidak mengandung unsur suara atau audio. Hal ini sejalan dengan pendapat Daryanto (1993: 27), menyatakan bahwa "media visual adalah alat peraga yang digunakan dalam proses belajar yang bisa dinikmati lewat panca indera mata".

Sedangkan Menurut Wati (2016: 21), media visual dapat dimaknai debagai berikut.

Media visual merupakan sebuah media yang memiliki beberapa unsur berupa garis, bentuk, warna, dan tekstur dalam penyajiannya. Media visual dapat menampilkan keterkaitan isi materi yang ingin disampaikan dengan kenyataan. Media visual dapat ditampilkan dalam dua bentuk, yaitu visual yang menampilkan gambar diam dan visual yang menampilkan gambar atau simbol gerak.

Pendapat tersebut semakin memberikan kejelasan bahwa media visual merupakan media yang memiliki garis, bentuk, warna, dan tekstur dalam penyajiannya untuk menampilkan isi materi yang ingin disampaikan sesuai dengan kenyataan dalam kehidupan sehari-hari.

Berdasarkan beberapa pendapat di atas, media visual adalah media yang hanya dapat dilihat saja, tidak mengandung unsur suara dan audio, yang memiliki garis, bentuk, warna, dan tekstur dalam penyajiannya yang menarik, agar mempermudah pemahaman siswa mengenai materi pembelajaran.

b. Kegunaan Media Visual

Media visual sangat penting untuk mendukung proses pembelajaran. Maka media visual memiliki beberapa kegunaan yaitu dapat memperjelas materi kepada siswa dan mendorong keaktifan serta minat belajar siswa agar mudah memahami materi. Sehingga proses pembelajaran di kelas dapat mencapai tujuan yang diharapkan.

Menurut Wati (2016: 30), kegunaan media visual sebagai berikut.

1) Fokus

Media visual berfungsi sebagai alat bantu untuk menarik dan mengarahkan perhatian siswa agar dapat berkonsentrasi pada materi pelajaran. Meteri pelajaran yang ditampilkan dengan media visual lebih efektif.

2) Antusias

Siswa sangat terbantu dengan hadirnya media visual pelengkap teks dalam pembelajaran. Sebab dengan media visual siswa lebih antusias 
dalam menyimak materi pelajaran. Siswa menjadi bersemangat dalam menganalisis dan berpendapat.

3) Mengarahkan

Seringkali siswa merasa bosan terhadap materi yang disampaikan hanya dalam bentuk teks. Materi yang ditampilkan dengan media visual siswa lebih diarahkan agar siswa tidak bosan untuk memperhatikan meteri pembelajaran.

4) Aktif

Media pembelajaran berbasis visual membuat siswa aktif di dalam kelas. Aktif dalam artian dapat mengikuti pelajaran dengan baik.

5) Informasi

Media pembelajaran berbasis visual membuat lambang-lambang visual yang dapat memperlancar siswa memahami dan mengingat materi atau informasi dalam pembelajaran.

6) Motivasi

Media pembelajaran berbasis visual membantu mengakomodasi siswa yang lemah dan lambat menerima dan mempelajari pelajaran yang ditampilkan tanpa menggunakan media.

\section{c. Macam-Macam Media Visual}

Teknologi dalam pendidikan pada dasarnya sangat penting sebagai alat komunikasi dalam proses pembelajaran, untuk menyampaikan pesan-pesan pendidikan kepada siswa. Penggunaan media dapat secara mandiri atau kombinasi dari beberapa media yang ada. Keterlibatan antara pendidikan dalam komunikasi bergantung pada media yang digunakan saat pembelajaran, pemanfaatan waktu dan tempat secara tepat, jenis informasi yang disampaikan, dan metode komunikasi yang dilaksanakan

Media pembelajaran berbasis visual merupakan salah satu alat bamtu menyampaikan informasi kepada siswa. Menurut Wati (2016: 24) macammacam media pembelajaran berbasis visual adalah sebagai berikut.

1) Media Visual Non Proyeksi

Salah satu jenis media visual yang sering digunakan dalam pembelajaran adalah media visual non proyeksi. Hal ini disebabkan dalam penggunaannya media visual non proyeksi berprinsip sederhana, yaiu tidak membutuhkan banyak kelengkapan dan alatnya tidak mahal.

a) Benda nyata

Benda nyata merupakan benda yang dapat dilihat, didengar, atau melahirkan pengalaman bagi siswa. Tujuan dari ditampilkannya benda nyata tersebut untuk memberikan pengalaman langsung kepada para siswa.

b) Model

Model merupakan benda tiruan dalam media visual non proyeksi. Model dapat ditampilkan dalam wujud tiga dimensi yang merupakan pengganti benda yang sesungguhnya.

c) Media cetak 
$\begin{array}{ll}\text { Volume } & 06 \\ \text { Nomor } & : 03 \\ \text { Bulan } & : \text { September } 2020 \\ \text { Tahun } & : 2020 \\ \text { http } & : \text { //ejurnal.pps.ung.ac.id/index.php/Aksara }\end{array}$

Media cetak merupakan media visual non proyeksi yang ditampilkan dalam bentuk tercetak. Media cetak termasuk kelompok media paling tua dan banyak digunakan dalam proses pembelajaran. sebab media cetak merupakan media yang praktisdigunakan dan banyak tersedia di berbagai tempat, seperti buku teks, moul, dan majalah.

d) Media grafis

Media grafis merupakan media visual non proyeksi yang dapat menyampaikan materi atau informasi melalui simbol-simbol visual. Sejauh ini media grafis merupakan media visual yang menarik perhatian, sebab dapat mengilustrasikan suatu konsep dengan jelas, seperti gambar, sketsa, diagram, dan bagan.

2) Media Visual Proyeksi

Media pembelajaran berbasis visual dapat ditampilkan dengan alat proyeksi atau proyektor. Dengan demikian objek lebih mudah dilihat dan diamati para siswa satu kegiatan pembelajaran.beberapa contoh media visual proyeksi adalah sebagai berikut.

a) Transparansi OHP

OHP merupakan perangkat media transparansi yang meliputi perangkat lunak atau Overhead Transparancy atau OHT dan perangka keras Overhead Projector atau OHP.

b) Film bingkai

Film bingkai merupakan film transparan sebagai media visual. Film bingkai serupa dengan transparansi OHP. Letak perbedaanya pada kualitas visual yang dihasilkan. Film bingkai memiliki kualitas yang lebih bagus.

d. Kelebihan dan Kekurangan Media Visual

Setiap media pembelajaran bertujuan membantu menyampaikan materi pembelajaran dengan baik. Pada media pembelajaran berbasis visual terdapat beberapa kelebihan dan kekurangan yang harus diperhatikan. Menurut Wati (2016: 39), kelebihan media pembelajaran berbasis visual adalah sebagai berikut:

1) Media visual membantu meningkatkan keefektifan pencapaian tujuan pembelajaran dengan bahan visual, 2) Media visual memperlancar proses pembelajaran, sehingga siswa dapat dengan mudah dan cepat menerima materi pembelajaran, 3) Media visual membantu siswa meningkatkan pemahaman dan memperkuat ingatan, sebab tampilan visual lebih menarik dari pada hanya tampilan verbal, 4) Media visual dapat dibaca berkali-kali dengan menyimpannya atau mengelipingnya, 5) Media visual membantu siswa berpikir tajam dan spesifik, 6) Media visual membantu mengatasi keterbatasan pengalaman yang dimiliki para siswa, 7) Media visual memungkinkan adanya interaksi antara siswa dengan lingkungan sekitarnya, 8) Media visual membantu penanaman 
konsep yang benar mengenai suatu informasi, dan 9) Media visual membantu membangkitkan keinginan dan minat baru para siswa.

Sedangkan dari sumber yang sama Wati (2016: 39), menyatakan bahwa kekurangan media visual antara lain: 1) Media visual tidak diikuti oleh audio. Sehingga kurang mendetail materi yang disampaikan, 2) Media visual seringkali ditampilkan dengan visual yang terbatas, dan 3) Media visual khususnya berbentuk cetak memerlukan biaya prodeksi cukup mahal".

Penyelesaian untuk kelemahan media visual dapat dilakukan dengan cara: 1) Media visual tanpa diikuti audio memiliki informasi yang kurang dalam memahami materi. Cara penyelesaiannya yaitu dengan cara memberi keterangan singkat dan jelas di bagian visual yang disajikan dan guru dapat memberikan informasi tambahan melalui penyampaian lisan, 2) Dengan keterbatasan visual yang hanya berupa gambar tanpa ada isi yang jelas terkait materi tersebut. Sebaiknya guru memberikan catatan penting di setiap gambar yang terkait dan dapat lebih diperluas informasi materi melalui penyampaian secara lisan, dan 3) Media visual berbentuk cetak memerlukan biaya mahal. Penyelesaiannya dengan cara guru harus memiliki jiwa kreatif sehingga dapat menggambar beberapa contoh yang menjelaskan materi yang akan disampaikan. Sehingga biaya produksi tidak akan mahal.

\section{SIMPULAN}

Penelitian kajian teoritik ini merupakan gagasan dalam konteks kegiatan belajar mengajar yang berupaya menanamkan konsep ilmiah dimana dalam proses pembelajaran siswa dapat mengembangkan rasa ingin tahu, menggali, mengkaji informasi, dan melakukan percobaan untuk memecahkan masalah. Salah satunya yaitu mata pelajaran ilmu pengetahuan alam (IPA). IPA merupakan ilmu pengetahuan tentang fenomena alam semesta yang tersusun secara sistematis saling berkaitan satu sama lainnya melalui proses penyelidikan, penyusunan, dan pengujian gagasan berupa metode ilmiah dengan cara melakukan berbagai percobaan sehingga dapat menarik suatu kesimpulan.

Salah satu model pembelajaran yang dimungkinkan untuk mewujudakan pembelajaran efektif pada pembelajaran IPA yaitu model pembelajaran Inside-Outside Circle (IOC). Model IOC merupakan konsep belajar yang terdiri dari kelompok lingkaran dalam dan luar yang bertujuan agar siswa secara mandiri dapat berlatih untuk menyampaikan informasi kepada orang lain. Model IOC memiliki langkah-langkah antara lain persiapan, pelaksanaan, simpulan materi, dan evaluasi. Meskipun model pembelajaran IOC memiliki kelemahan yaitu membutuhkan ruang kelas yang besar dan terlalu lama yang ditengarai tidak konsentrasi serta rumit untuk dilakukan. Namun ada cara untuk mengatasi kelemahan model pembelajaran IOC tersebut yaitu guru dapat menggunakan fasilitas yang disediakan sekolah yaitu aula yang cukup luas sehingga proses pembelajaran akan berjalan secara efektif dan menerapkan time limit atau batasan waktu, dan agar tidak terjadi kerumitan dalam pelaksanaan, maka sebelum proses pembelajaran dilaksanakan, sebaiknya guru memberikan penjelasan terlebih dahulu.

Disamping penggunaan model pembelajaran guru dapat menggunakan media pembelajaran yang kreatif yaitu media yang dikreasi sedemikian rupa sehingga lebih menarik minat belajar dan membangun antusiasme dalam proses pembelajaran. Dari sekian banyak macam media pembelajaran, yang dipertimbangkan efektif sebagai 


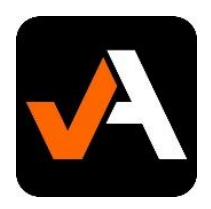

$\begin{array}{ll}\text { Volume } & 06 \\ \text { Nomor } & : 03 \\ \text { Bulan } & : \text { September } 2020 \\ \text { Tahun } & : 2020 \\ \text { http } & : \text { //ejurnal.pps.ung.ac.id/index.php/Aksara }\end{array}$

pendukung dalam pelaksanaan pembelajaran, salah satunya yaitu media visual. Media visual merupakan media yang dapat dilihat, tidak mengandung suara, memiliki bentuk, warna, dan tekstur dalam penyajiannya yang menarik agar siswa tidak bosan dan pasif. Meskipun media visual memiliki kelemahan yaitu tidak diikuti audio, terbatas, dan biaya cukup mahal. Untuk mengatasi kelamahan tersebut guru dapat memberikan keterangan singkat dan jelas di bagian visual yang disajikan, guru memberikan catatan penting di setiap gambar yang terkait dan dapat lebih diperluas informasi materi melalui penyampaian secara lisan, dan guru harus memiliki jiwa kreatif sehingga dapat menggambar beberapa contoh yang menjelaskan materi yang akan disampaikan.

\section{DAFTAR PUSTAKA}

Aqib, Zainal. 2013. Model-Model, Media, dan Strategi Pembelajaran Kontekstual (inovatif). Bandung: Yrama Widya.

Azhar, Arsyad. 2009. Media Pembelajaran. Jakarta: Raja Grafindo Perkasa.

Bundu, Patta. 2006. Penilaian Keterampilan Proses dan Sikap Ilmiah dalam Pembelajaran Sains di SD. Jakarta: Depdiknas.

Daryanto. 1993. Media Visual untuk Pengajaran Teknik. Bandung: Tarsito.

Daryanto. 2014. Pembelajaran Tematik, Terpadu, Terintegrasi (Kurikulum 2013). Yogyakarta: Gava Media.

Huda, Miftahul. 2013. Model-Model Pengajaran dan Model Pembelajaran. Yogyakarta: Pustaka Pelajar.

Norhayati, Eni. 2006. Teori Ringkas Latihan Soal dan Pembahasan IPA SD Kelas IV, V, VI. Yogyakarta: Intersolusi Pressindo.

Rusman. 2013. Model-Model Pembelajaran. Jakarta: PT Rajagrafindo Persada.

Samatowa, Usman. 2011. Pembelajaran IPA di Sekolah Dasar. Jakarta: PT Indeks.

Sanjaya, Wina. 2008. Perencanaan dan Desain Sistem Pembelajaran. Bandung: Kencana Prenada Media Group

Shoimin, Aris. 2014. 68 Model Pembelajaran Inovatif Dalam Kurikulum 2013. Yogyakarta: AR-Ruzz Media.

Sundayana, Rostina. 2013. Media Pembelajaran Matematika. Bandung: CV Alfabeta.

Susanto, Ahmad. 2013. Teori Belajar Pembelajaran di Sekolah Dasar. Jakarta: PT. Fajar Interpratama Mandiri.

Suyatno. 2009. Menjelajah Pembelajaran Inovatif. Sidoarjo: Masmedia Buana Pusaka.

Wati, Ega Rima. 2016. Ragam Media Pembelajaran. Yogyakarta: Kata Pena.

Lampiran Peraturan Menteri Pendidikan dan Kebudayaan Nomor 21 Tahun 2016 Tentang Standar Isi Pendidikan Dasar dan Menengah https://bnsp-indonesia.org (diunduh 26 April 2020). 